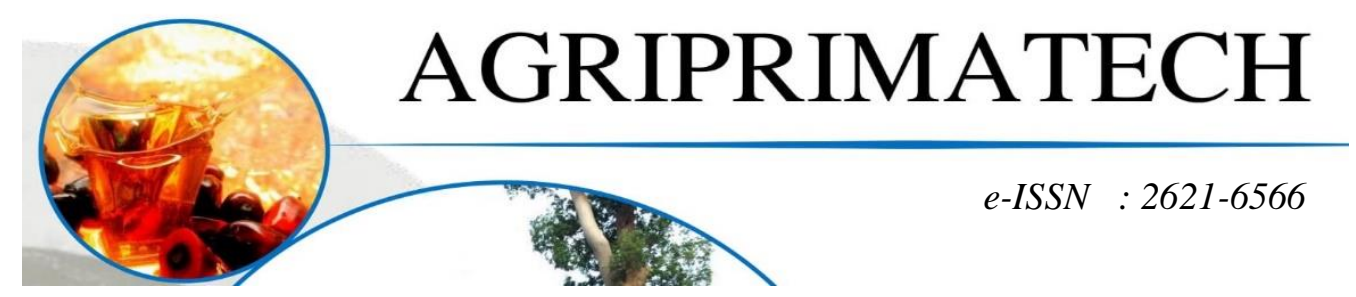

\title{
PENGARUH KARAKTERISTIK TERHADAP PENDAPATAN PETANI KELAPA SAWIT
}

\author{
LAURA JUITA PINEM ${ }^{1}$ \\ ${ }^{1}$ Fakultas Agro Teknologi, Universitas Prima Indonesia \\ E-mail : laurajuitapinem@unprimdn.ac.id
}

\begin{abstract}
ABSTRAK
Penelitian ini bertujuan untuk mengetahui pengaruh tingkat pendidikan, lama berusahatani dan luas lahan yang dimiliki petani kelapa sawit terhadap pendapatan petani kelapa sawit. Penelitian ini dilakukan di Desa Marjanji, Kecamatan Sipispis Kabupaten Serdang Bedagai. Penelitian ini melibatkan 91 responden yang keseluruhannya merupakan petani kelapa sawit. Data yang diperoleh dianalisis dengan menggunakan regresi linier berganda. Hasil analisis menunjukkan bahwa tingkat pendidikan, lama berusahatani dan luas lahan mempengaruhi pendapatan petani di Desa Marjanji pada selang kepercayaan 95 persen. Model penelitian yang digunakan menunjukkan koefisien determinasi sebesar 70 persen yang menunjukkan bahwa faktor tingkat pendidikan, lama berusahatani, dan luas lahan merupakan 70 persen dari faktor yang mempengaruhi tingkat pendapatan petani kelapa sawit di Desa Marjanji sementara 30 persen lainnya berasal dari luar model yang digunakan.
\end{abstract}

Kata Kunci: Pendidikan, Kelapa Sawit, Lama Berusahatani, Karakteristik

\section{Pendahuluan}

Kelapa sawit (Elaeis guineensis Jacq.) merupakan komoditas tanaman perkebunan yang cukup banyak ditanam di perkebunan-perkebunan di Indonesia. Melalui produk olahannya yaitu minyak sawit, kelapa sawit menjadi salah satu komoditas perkebunan yang handal. Ini disebabkan oleh tingginya permintaan minyak kelapa sawit baik di dalam negeri maupun di luar negeri. Serta beragamnya kegunaan minyak kelapa sawit sebagai bahan baku industri pangan dan non pangan yang memberikan prospek lebih cerah dibandingkan komoditas perkebunan lainnya. Kelapa sawit juga memiliki peran penting dalam kegiatan perekonomian baik di pasar domestik maupun di pasar internasional.
Berdasarkan data Kementerian Pertanian (2020) dalam kurun waktu 2010-2018, konsumsi minyak sawit domestik meningkat hampir 50 persen sedangkan konsumsi minyak kelapa sawit dunia mencapai angka 78.58 juta ton pada tahun 2019 (Radar,2020).

Benih merupakan salah satu faktor yang menjadi penentu keberhasilan dari usahatani kelapa sawit. Banyaknya petani yang menggunakan benih nonsertifikat menyebabkan rendahnya produktifitas dari perkebunan rakyat. Produktfitas tanaman kelapa sawit milik rakyat saat ini hanya 2-3 ton/Ha/bulan karena penggunaan benih yang tidak mementingkan kualitas sementara bila petani menggunakan benih bersertifikat maka petani mampu menaikan produktifitas lebih tinggi (GAPKI, 2018). 
Hal ini juga didukung oleh data yang dirilis oleh Direktorat Jendral Perkebunan pada tahun 2019, luas areal perkebunan yang terdapat di Indonesia, 41,35 persen merupakan Perkebunan Rakyat, namun produksi kelapa sawit yang dihasilkan oleh perkebunan rakyat hanya sekitar 34 persen (BPS,2020).

Produksi kelapa sawit merupakan salah satu tolak ukur pendapatan yang diperoleh petani. Sampai saat ini pendapatan masih menjadi tolak ukur bagi kesejateraan dan status sosial masyarakat. Perbedaan nilai pendapatan yang terlalu jauh akan menyebabkan masalah-masalah sosial di tengah-tengah masyarakat. Pendidikan merupakan merupakan salah satu medium yang dapat digunakan dalam proses transmisi tekhologi yang diharapkan mampu untuk mendorong peningkatan pendapatan petani. Masyarakat meyakini bahwa semakin tinggi tingkat pendidikan maka akan semakin tinggi pula tingkat pendapatan yang akan diperoleh. Selain pendidikan, luas yang dimiliki petani dan pengalaman berusahatani yang dimiliki petani juga turut memberikan kontribusi terhadap pendapatan yang dihasilkan petani.

Berdasarkan fakta yang

berkembang di masyarakat, penelitian ini dilakukan dengan tujuan untuk menganalisis mengenai pengaruh tingkat pendidikan, lama berusahatani dan luas lahan yang dimiliki petani terhadap pendapatan yang diperoleh petani. Lokasi yang dipilih adalah Desa Marjanji Kabupaten Serdang Bedagai.

\section{Metode}

Penelitian dilaksanakan di Desa Marjanji, Kecamatan Sipispis, Kabupaten Serdang Bedagai, Propinsi Sumatera Utara. Lokasi ditetapkan sebagai tempat penelitian secara purposive dengan pertimbangan bahwa Desa tersebut merupakan salah satu kabupaten yang memiliki potensi untuk pengembangan komoditas kelapa sawit di Sumatera Utara dan selain itu terdapat terdapat banyak petani rakyat yang menggantungkan hidup pada komoditas kelapa sawit di Desa tersebut. Penelitian dilakukan pada tahun 2021.
Data yang digunakan pada penelitian ini adalah data primer yang didapat dengan melakukan penyebaran kuisioner kepada petani kelapa sawit yang berada di Desa Marjanji. Populasi petani di Desa Marjanji sebesar 960 orang. Sebanyak 91 orang dari populasi digunakan sebagai sampel penelitian.

Data yang telah dikumpulkan kemudian dianalisis dengan menggunakan regresi linier berganda. Menurut Suharyadi dan Purwanto (2004) Analisis regresi linier berganda merupakan regresi linier untuk menganalisis besarnya hubungan variable dependen dan pengaruh variable independen yang jumlahnya lebih dari dua. Model regresi linier berganda yang digunakan dalam penelitian ini adalah :

\section{Dimana :}

$$
Y=a+b_{1} X_{1}+b_{2} X_{2}+b_{3} X_{3}
$$

$$
\begin{array}{ll}
\text { Y } & \text { : Tingkat Pendapatan (Rupiah) } \\
\text { a } & \text { : Bilangan Konstanta }
\end{array}
$$

$b_{1}, b_{2}, b_{3}$ :Koefisien arah regrasi yang menyatakan perubahan nilai $Y$

X1 : Tingkat Pendidikan (Tahun)

X2 : Lama Berusaha Tani (Tahun)

X3 : Luas Lahan $(\mathrm{Ha})$

Uji $F$ digunakan untuk menguji pengaruh variabel independen secara bersama - sama terhadap variable dependen. Hipotesis yang digunakan dalam penelitian adalah :

Ho : Diduga variabel tingkat pendidikan $\left(X_{1}\right)$, lama berusahatani $\left(X_{2}\right)$, luas lahan $\left(X_{3}\right)$, secara bersama - sama tidak berpengaruh dalam meningkatkan pendapatan petani kelapa sawit di Desa Marjanji Kecamatan Sipispis.

$\mathrm{Ha}$ : Diduga variabel tingkat pendidikan $\left(X_{1}\right)$, lama berusahatani $\left(X_{2}\right)$, luas lahan $\left(X_{3}\right)$ secara bersama - sama berpengaruh dalam meningkatkan pendapatan petani kelapa sawit di Desa Marjanji Kecamatan Sipispis.

Kriteria penolakan atau penerimaan

a. Fhitung $\leq$ Ftabel maka Ho diterima dan $\mathrm{Ha}$ ditolak. Hal ini berarti tidak terdapat pengaruh simultan oleh variable $\mathrm{X}$ dan $\mathrm{Y}$. b. Fhitung $\geq$ Ftabel maka Ho ditolak dan $\mathrm{Ha}$ diterima. Hal ini berarti terdapat pengaruh yang simultan terhadap variable $\mathrm{X}$ dan $\mathrm{Y}$.

Uji selanjutnya yang dilakukan pada penelitian ini adalah uji t. Uji $t$ diperlukan untuk melakukan pengujian 
terhadap koefisien regresi secara parsial. Pengujian ini diharapkan dapat memperlihatkan signifikansi peran secara parsial antara variabel independen terhadap variabel dependen dengan mengasumsikan bahwa variabel independen lain dianggap konstan.

Dasar pengambilan keputusan untuk Uji T sebagai berikut:

a. Berdasarkan nilai t hitung dan $t$ tabel

1) Jika nilai $t$ hitung $>t$ tabel maka variabel independen berpengaruh terhadap variabel terikat.

2) Jika nilai $t$ hitung $<t$ tabel maka variabel independen tidak berpengaruh terhadap variabel terikat.

b. Berdasarkan nilai signifiknasi

1) Jika nilai Sig. < 0,05 maka variabel bebas berpengaruh signifikan terhadap variabel terikat.

2) Jika nilai Sig. > 0,05 maka variabel bebas tidak berpengaruh signifikan terhadap variabel terikat.

\section{Hasil dan Pembahasan}

Petani adalah pelaku paling utama dalam kegiatan produksi pertanian dan juga merupakan bagian dari masyarakat Indonesia yang perlu ditingkatkan kesejahteraannya. Banyak cara yang bisa dilakukan untuk meningkatkan kesejahteraan petani terutama dalam penelitian ini dikhususkan pada petani kelapa sawit, diantaranya adalah peningkatan produktifitas tanaman melalui penyuluhan. Penyuluhan yang dilakukan akan lebih efektif jika karakteristik petani dapat dianalisis dengan benar.

\section{Karakteristik Petani}

Karakteristik petani kelapa sawit merupakan ciri-ciri atau sifat-sifat yang dimiliki oleh petani yang dapat dianalisis melalui pola pikir, pola sikap dan pola tindakan terhadap lingkungannya (Mislini, 2006). Ciri-ciri atau sifat-sifat yang dimiliki oleh petani meliputi beberapa faktor atau unsur-unsur yang melekat pada diri seseorang dapat dikatakan sebagai karakteristik petani.

\section{a. Tingkat Pendidikan}

Tingkat pendidikan dapat diartikan sebagai tahapan pendidikan yang ditetapkan berdasarkan tingkat kemampuan menyerap informasi dan kemampuan untuk mengimplementasikan informasi tersebut dalam kehidupan seharihari. Menurut Suhardjo (2007) tingkat pendidikan formal yang dimiliki oleh seseorang membentuk nilai orang tersebut. Pendidikan yang dimiliki oleh petani kelapa sawit diharapkan dapat membantu petani dalam menyerap setiap informasi yang berhubungan dengan kegiatan usahatani kelapa sawit yang dijalankan. Pendidikan yang dimiliki petani juga diharapkan dapat mempermudah petani dalam memahami dan menggunakan teknologi dan manajemen dalam mengelola usahatani kelapa sawit.

Data yang diperoleh dari responden menunjukkan bahwa sebanyak 68,1 persen petani telah menamatkan pendidikan di jenjang Sekolah Menengah Atas (SMA). Pendidikan tertinggi petani di Desa Marjanji adalah diploma dengan presentase sebesar 3,3 persen. Tingkat pendidikan yang dimiliki petani diharapkan sudah mampu untuk mempengaruhi pola pikir dan daya nalar petani karena tingkat pendidikan yang tinggi mampu mengarahkan petani kelapa sawit untuk bertindak secara rasional untuk menjalankan usahatani kelapa sawitnya. Hal yang sama juga dikemukakan Afrizon pada tahun 2012 pada penelitian yang dilakukannya. Data tingkat pendidikan petani kelapa sawit di Desa Marjanji dapat dilihat pada Gambar 1. 


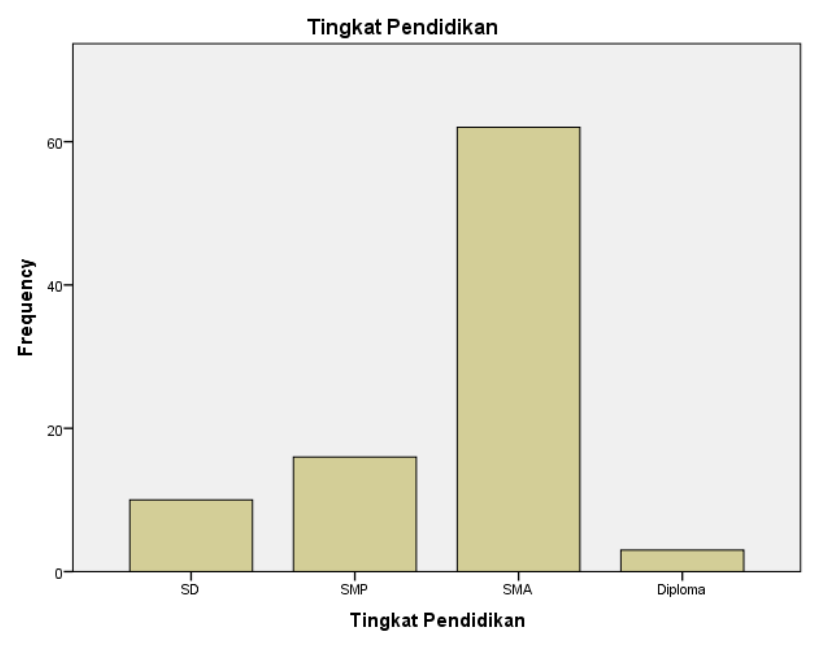

Gambar 1. Karakteristik petani kelapa sawit Desa Marjanji berdasarkan tingkat pendidikan

b. Lama Berusahatani

\begin{tabular}{|c|}
\hline $\begin{array}{l}\text { tinitas kegiatannya sehar } \\
\text { au peristiwa yang pe } \\
\text { alaminya dalam melak } \\
\text { sahatani. Pengalaman } \\
\text { miliki oleh petani merup } \\
\text { alah satu modal usaha d } \\
\text { entuk pengetahuan yang c } \\
\text { gunakan dalam memeca } \\
\text { tiap permasalahan yang diha } \\
\text { etani selama berusaha } \\
\text { engalaman petani } \\
\text { gunakan sebagai guru yang } \\
\text { mana dalam mempers } \\
\text { rhadap sesuatu obyek bias } \\
\text { dasarkan atas pengala } \\
\text { eseorang. Melalui pengala. }\end{array}$ \\
\hline
\end{tabular}

seorang petani yang berhasil mempunyai pengetahuan, sikap dan keterampilan yang lebih baik, dibandingkan dengan petani yang kurang berpengalaman.

Bedasarkan kuisioner yang digunakan sebagai alat analisis, didapatkan data yang beragam mengenai pengalaman berusahatani petani di Desa Marjanji. Sebanyak 42,9 persen petani memiliki pengalaman berusahatani selama 11-15 tahun, sebanyak 31,9 persen petani lainnya memiliki pengalaman berusahatani selama 6-10 tahun, bahkan terdapat 3,3 persen petani yang memiliki pengalaman berusahatani kelapa sawit lebih dari 20 tahun. Gambar 3 menunjukkan karakteristik petani berdasarkan lama berusahatani. Pengalaman petani yang semakin banyak akan berbanding lurus dengan minat petani untuk mengusahakan usahataninya. Pengalaman yang banyak tersebut juga akan melatih petani untuk mempunyai kemampuan dan kematangan dalam mempertimbangkan setiap langkah keputusan yang berkaitan dengan usahatani kelapa sawit yang dikelola petani tersebut sehingga mampu mencapai produktifitas yang 
maksimal. Hasil yang sama juga diperoleh oleh Edwina yang melakukan penelitian penelitian pada karakteristik petani kelapa

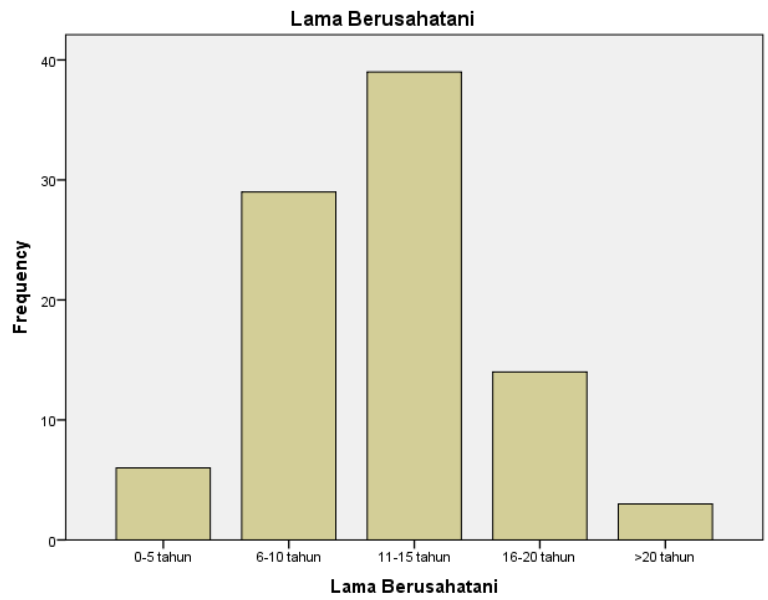

sawit pada program Siska di Kabupaten Pelalawan pada tahun 2014.

Gambar 2. Karakteristik petani kelapa sawit Desa Marjanji berdasarkan lama berusahatani

\section{c. Luas Lahan}

Lahan pertanian dapat didefinisikan sebagai lahan yang ditujukan atau memiliki kecocokan untuk dijadikan lahan usahatani untuk memproduksi tanaman pertanian maupun hewan ternak. Lahan pertanian merupakan salah satu sumber daya utama pada usaha pertanian. Lahan merupakan salah satu faktor penting dalam usahatani yang memberikan kontribusi besar terhadap pendapatan petani. Besar kecilnya produksi dari usaha tani antara lain dipengaruhi oleh luas sempitnya lahan yang digunakan ( Mubiyarto, 1989). Penelitian yang dilakukan oleh Edwina tahun 2014 juga berpendapat bahwa besar kecilnya lahan mempengaruhi besar kecilnya pendapatan yang diperoleh oleh petani dari usahatani.

Data yang diperoleh pada penelitian menunjukkan bahwa sebanyak 95.5 persen petani memiliki luas lahan dibawah 2 hektar. Luas lahan yang dimiliki oleh petani kelapa sawit di Desa Marjanji tergambar pada Gambar 3.

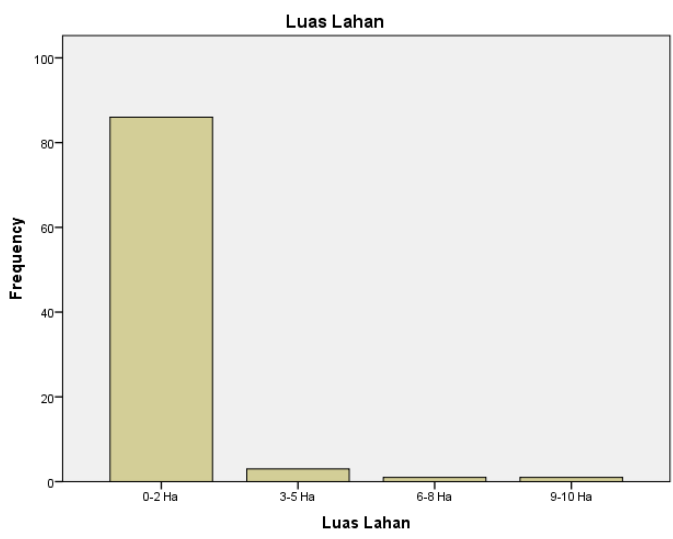

Gambar 3. Karakteristik petani kelapa sawit Desa Marjanji berdasarkan luas lahan 
memerlukan uji validitas dan realibilitas agar data yang diperoleh dari kuisioner tidak bias. Uji Validitas merupakan uji yang dilakukan untuk mengetahui tingkat kevalidan dari setiap pertanyaan yang terdapat pada kuisioner yang digunakan dalam pengumpulan data yang di peroleh dengan cara mengkorelasi setiap skor variabel jawaban responden dengan total skor masing-masing variabel. Sedangkan uji reliabilitas merupakan uji yang menggambarkan suatu konsistensi alat ukur dalam menghasilkan data. Data yang diperoleh disebut konstan apabila data yang dihasilkan dari pengukuran dengan alat yang sama dan berulang-ulang akan menghasilkan data yang relatif sama.

Data yang analisis dengan menggunakan SPSS terhadap kuisoner penelitian menunjukkan bahwa nilai $r$ hitung pada variabel $X_{1}, X_{2}, X_{3}$ dan $Y$ dari masing-masing variabel memiliki nilai $>r$ tabel yaitu sebesar 0.1735. Hal ini menunjukkkan bahwa instrumen pada penelitan ini adalah valid dan alat ukur tersebut dapat digunakan untuk mengukur penelitian ini.

Disisi lain uji realibilitas terhadap kusioner juga menunjukkan hal sama. Pengujian dengan SPSS menunjukkan bahwa nilai Alpha's Cronbach pada variabel $X_{1}, X_{2}, X_{3}$, dan $Y$ masing-masing variabel memiliki nilai $>0.600$. sehingga dapat disimpulkan bahwa instrumen penelitian ini reliabel untuk digunakan pada penelitian.

\section{Analisis Regresi Linier Berganda}

Analisis regresi linier berganda merupakan bagian dari regresi linier yang digunakan untuk menganalisis hubungan antara variabel dependen dan variabel independen yang jumlahnya lebih dari dua (Suharyadi,2004). Terdapat dua uji dalam regresi berganda yaitu Uji $\mathrm{T}$ dan $\mathrm{Uji} \mathrm{F}$. Analisis yang dilakukan dengan menggunakan aplikasi SPSS versi 23 menghasilkan hasil regresi linier berganda seperti yang tertera dalam tabel berikut :

Tabel 1. Hasil analisis regresi linier berganda dengan SPSS

\begin{tabular}{lccc}
\hline \multicolumn{1}{c}{ Variabel } & Koefisien Regresi & t-hitung & Sig. \\
\hline Konstanta (a) & 0.344 & 2.708 & 0.008 \\
Tingkat Pendidikan $\left(\mathrm{X}_{1}\right)$ & 0.184 & 5.034 & 0.000 \\
Lama Berusahatani $\left(\mathrm{X}_{2}\right)$ & 0.176 & 5.470 & 0.000 \\
Luas Lahan $\left(\mathrm{X}_{3}\right)$ & 0.606 & 9.516 & 0.000 \\
$\mathrm{R}$ & $=0.838$ & & \\
$\mathrm{R}^{2}$ & $=0.702$ & & \\
F-Hitung & $=68.401$ & & \\
$\mathrm{~N}$ & $=91$ & & \\
\hline
\end{tabular}

Tabel di atas menghasilkan model persamaan penelitian sebagai berikut :

$$
Y=0.344+0.184 X_{1}+0.176 X_{2}+0.606 X_{3}
$$

Seluruh koefisien regresi dari persamaan di atas menunjukkan bahwa semua variabel bebas (tingkat pendidikan, lama berusahatani dan luas lahan) memiliki koefisien bi yang positif sehingga dapat diartikan bahwa tingkat pendidikan, lama berusahatani dan luas lahan ditingkatkan maka akan meningkatkan pendapatan petani kelapa sawit di Desa Marjanji, atau seluruh variabel bebas mempunyai pengaruh yang searah terhadap variabel $Y$ (pendapatan). Variabel luas lahan $\left(X_{3}\right)$ memiliki kontribusi relatif yang paling besar di antara ketiga variabel bebas terhadap pendapatan petani kelapa sawit di Desa Marjanji.

Nilai koefisien determinan $\left(R^{2}\right)$ yang dihasilkan pada penelitian ini adalah sebesar 0.702. Nilai ini menunjukkan bahwa sebesar 70.2 persen faktor yang mempengaruhi pendapatan petani kelapa sawit di Desa Marjanji dapat di jelaskan oleh variasi faktor yang digunakan dalam model. sedangkan sisanya 29.8 persen dapat dipengaruhi oleh faktor lain yang terdapat di luar model. 


\section{Pengujian secara simultan (Uji F)}

Uji $F$ digunakan untuk melihat hubungan variabel independen dan variabel dependen secara bersama sama. Berikut merupakan tabel uji F untuk penelitian ini.

Tabel 2. Analisis Variasi Hubungan Karakteristik Terhadap Pendapatan Petani Kelapa Sawit di Desa Marjanji

\begin{tabular}{llccccc}
\hline Model & Sum of Squares & df & Mean Square & F & Sig. \\
\hline 1 & Regression & 11.869 & 3 & 3.956 & 68.401 & $.000^{\mathrm{b}}$ \\
& Residual & 5.032 & 87 & .058 & & \\
Total & 16.901 & 90 & & & \\
\hline
\end{tabular}

a. Dependent Variable: Pendapatan

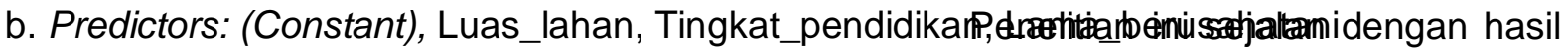
penelitian yang dilakukan

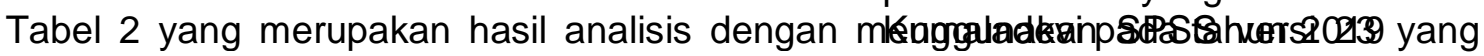
menunjukkan bahwa $\mathrm{F}$ hitung yang dihasilkan adalah sebresary

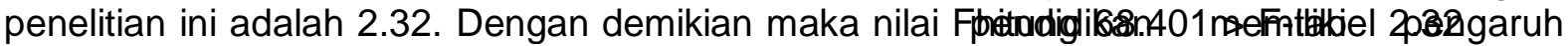
sehingga dapat disimpulkan bahwa Ho ditolak danteltradkiperimangkeatg aptimydatan menunjukkan bahwa secara bersama-sama (simultandettamg.kat pendidikan, lama berusahatani dan luas lahan berpengaruh secara bignffidkgartemhadkonpendlapataahatani petani kelapa sawit di Desa Marjanji.

terhadap pendapatan petani

Data yang ditampilkan pada

\section{Pengujian secara parsial (Uji t)}

Uji t merupakan uji yang digunakan untuk mengetahui pengaruh masingmasing variabel terhadap pendapatan petani kelapa sawit di Desa Marjanji, jika tingkat signifikan yang dihasilkan $<0,05$ berarti $\mathrm{H}_{0}$ akan ditolak dan $\mathrm{Ha}$ diterima. $\mathrm{Hal}$ ini menyatakan bahwa ada pengaruh yang signifikan antara variabel karakteristik petani terhadap pendapatan petani. Namun jika tingkat signifikan yang dihasilkan > 0,05 berarti $\mathrm{H}_{0}$ diterima dan $\mathrm{H}_{a}$ ditolak. Hal ini menyatakan bahwa tidak terdapat pengaruh yang signifikan antara variabel karakteristik petani terhadap pendapatan petani.

a. Pengaruh tingkat pendidikan terhadap pendapatan petani

Tabel 1 menunjukkan bahwa nilai signifikasi dari variabel tingkat pendidikan adalah 0.000 . Nilai tersebut lebih kecil dari tingkat signifikansi 0.05 . Hal yang sama ditunjukkan oleh t hit, yaitu 5.034, yang menunjukkan angka yang lebih besar dari t-tabel, yaitu 1.988 . $\mathrm{Hal}$ ini menunjukkan bahwa $\mathrm{H}_{0}$ akan ditolak dan $\mathrm{Ha}$ diterima, berarti terdapat pengaruh yang signifikan antara tingkat pendidikan dengan pendapatan petani.
Tabel 1 menunjukkan bahwa nilai signifikasi dari variabel tingkat pendidikan adalah 0.000 . Nilai tersebut lebih kecil dari tingkat signifikansi 0.05 . Hal yang sama ditunjukkan oleh t hit, yaitu 5.470, yang menunjukkan angka yang lebih besar dari t-tabel, yaitu 1.988. $\mathrm{Hal}$ ini menunjukkan bahwa $\mathrm{H}_{0}$ akan ditolak dan $\mathrm{Ha}$ diterima, berarti terdapat pengaruh yang signifikan antara lama berusahatani dengan pendapatan petani. Penelitian ini sejalan dengan hasil penelitian yang dilakukan Kumaladevi pada tahun 2019 yang menyatakan bahwa tingkat pendidikan memiliki pengaruh terhadap tingkat pendapatan petani.

c. Pengaruh luas lahan terhadap pendapatan petani

Data yang ditunjukkan pada Tabel 1 menunjukkan bahwa nilai signifikasi dari variabel tingkat pendidikan adalah 0.000 . Nilai tersebut lebih kecil dari tingkat signifikansi 0.05 . Hal yang sama ditunjukkan oleh t hit, yaitu 0.606, yang menunjukkan angka yang lebih besar dari t-tabel, yaitu 1.988 . 
